Available online at website :

http:/ / e-journal.adpgmiindonesia.com/index.php/jmie

JMIE: Journal of Madrasah Ibtidaiyah Education, 5(1), 2021, 124-140

\title{
MODEL KEBIJAKAN PENDIDIKAN DASAR ISLAM DI INDONESIA ERA PANDEMI COVID-19
}

\author{
Muh. Syauqi Malik'), Erni Munastiwi²) \\ Universitas Islam Negeri Sunan Kalijaga Yogyakarta \\ Email: 19204080006@student.uin-suka.ac.id ${ }^{1)}$,erni.munastiwi@uin-suka.ac.id ${ }^{2)}$
}

Submit: 20 Juli 2020, Revisi: 17 April 2021, Approve:19 Mei 2021

\begin{abstract}
The COVID-19 pandemic was very unexpected, came very suddenly. Various sectors were affected, not only in Indonesia but also overseas. The most highlighted sector in this research is the education sector, and the education sector needs attention because education determines civilization's progress. Besides, primary education is the basis for higher education. This research focuses on the model of Islamic basic education policy in the era of the COVID-19 pandemic. Researchers used a qualitative approach to literature studies and case studies to test the policy model in more detail. The research subjects in this study included the Ministry of Education and Culture, the Ministry of Religion, the National Education Standards Agency, and the Head of MI Salafiyah Tajungsari, Tlogowungu District, Pati Regency. Data collection techniques using observation, interviews, and documentation. Data analysis used data reduction, data presentation, concluding, and verification. The method of testing the researchers' data validity was obtained by triangulating methods and triangulation of sources. The results show that the policy model issued by the Ministry of Education and Culture, Ministry of Religion, Government, and Madrasah is uncertain, meaning that it always develops following the development of COVID-19 in the area. Learning is carried out online using various supporting tools such as WhatsApp Group, Google Classroom, Google Forms, Video Conference, and others tailored to the conditions and situation of the local community. The policy model taken has gone through deliberation by experts so that the teaching and learning process continues even though it has to go through various obstacles and obstacles.
\end{abstract}

Keywords: Keywords: Policy, Islamic Basic Education, COVID-19.

Pengutipan: Muh. Syauqi Malik \& Erni Munastiwi. (2021). Model Kebijakan Pendidikan Dasar Islam di Indonesia Era Pandemi Covid-19. JMIE: Journal of Madrasab Ibtidaiyah Education, 5(1), 2021, 124-140. jmie.v5i1.223.

Permalink/DOI: http://dx.doi.org/10.32934/jmie.v5i1.223 



\section{PENDAHULUAN}

Dunia sedang merana, mungkin kata itu yang tepat untuk mengilustrasikan situasi saat ini. Bagaimana tidak, manusia yang fitrahnya merupakan makhluk sosial diminta untuk menjaga jarak dengan sesama sehingga muncul istilah social distancing. Silaturahmi secara langsung dilarang keras oleh pemerintah, membuat acara yang melibatkan banyak orang baik dalam nuansa suka ataupun duka tidak diperbolehkan, lebih miris lagi tempat ibadah disegel dengan garis kuning polisi padahal mau kemana lagi tempat mengadu kalau bukan kepada Tuhan Yang Maha Esa. Angka pengangguran semakin meningkat, sedangkan kebutuhan untuk melangsungkan kehidupan tetap harus berjalan. Derai air mata semakin deras, kerinduan pada kampung halaman tidak kunjung terobati. Semuanya menjadi sundzdzon antara satu dengan yang lainnya. Bersalamsalaman dalam hadis Nabi merupakan penggugur dosa, sedangkan saat ini berubah menjadi ancaman kesehatan. Toko retail, UMKM, Ojek Online, Buruh, Pedagang, dan hampir semua sektor perekonomian menurun (untuk tidak mengatakan lumpuh).

Selain di sektor ekonomi, dampak terbesar yang dirasakan saat ini terjadi di sektor pendidikan. Dengan diterapkannya pembatasan interaksi secara langsung, maka pembelajaran dilakukan melalui daring (dalam jaringan). Meskipun begitu, tentu tak bisa dikatakan proses pendidikan sedang baik-baik saja, banyak sekali problematika yang dialami oleh siswa maupun pendidik, bahkan wali murid. Seperti halnya tak semua daerah mampu menggunakan jaringan dengan baik, tak semua lapisan masyarakat mampu untuk membeli paket data, bahkan lebih mirisnya untuk makan saja tak ada. Selain itu, tak semua wali murid memiliki background pendidikan tinggi yang mampu membimbing secara mandiri putra-putri tersayangnya di rumah, pekerjaan wali murid juga terganggu karena harus ikut mendampingi anaknya.

COVID-19 (Corona Virus Disease-19) namanya sepintas terlihat indah, tapi dampaknya sangat mengerikan. Virus ini disinyalir sebagai penggagas yang mengakibatkan berbagai problem yang penulis paparkan di atas. Bukan hanya di Indonesia, WHO (World Health Organization) mengungkapkan wabah COVID-19 dijadikan pandemi dunia saat ini, namun muncul dua pendapat mengenai penyebutan pandemi. Pertanyaan pertama adalah mengapa ada keengganan untuk menyebut wabah COVID-19 sebagai pandemi, dan pertanyaan kedua adalah apakah terminologinya memiliki kepentingan praktis. Di hampir semua buku teks yang bagus, epidemi menjadi pandemi ketika ada distribusi geografis yang luas dari penyakit ini. Selama beberapa minggu, epidemi COVID-19, telah merambah ke lebih dari 100 negara, tampaknya sesuai dengan definisi klasik pandemi. Orang bisa bertanya apakah penggunaan istilah pandemi akan mengubah tindakan yang diperlukan untuk mengendalikan penyebaran virus. Ada beberapa situasi yang bisa membantu menggunakan terminologi yang terdefinisi dengan baik untuk mengendalikan penyebaran penyakit menular. Sumber daya untuk mengendalikan pandemi keduanya berbeda, jauh lebih besar, dan umumnya jauh lebih luas daripada wabah lokal atau epidemi. Dengan demikian istilah yang digunakan untuk situasi yang berbeda dapat dibatasi sesuai dengan langkahlangkah kontrol yang diperlukan (Mehta dkk., 2020).

WHO memberlakukan social and physical distancing sebagai alat dalam memutus penyebaran COVID-19 agar dapat mencegah penularan. Berbagai langkah yang ditempuh dengan menjaga jarak minimal satu meter, mengurangi sentuhan terhadap barang-barang yang 
rawan terkontaminasi seperti gagang pintu, menggunakan media sosial berupa virtual untuk menjaga komunikasi (menghindari kerumunan). Langkah-langkah untuk masyarakat umum termasuk dalam memperkenalkan work from home pembelajaran online, mengurangi kerumunan, menutup beberapa layanan yang kurang bermanfaat, pembatasan transaksi baik secara lokal ataupun nasional, serta menyuarakan aktivitas dari rumah (Organization, 2020). COVID-19 dalam pemberitaan nasional maupun internasional telah menewaskan banyak jiwa, namun mau tidak mau roda kehidupan harus tetap berjalan dengan optimal terutama di sektor pendidikan karena pendidikan yang membuat derajat manusia lebih tinggi di mata sesama maupun di hadapan Tuhannya. Pendidikan harus tetap berjalan bagaimanapun kondisi yang sedang dialami, ini merupakan hal yang sulit karena belum pernah dialami sebelumnya.

Kajian penelitian yang relevan diantaranya, pertama penelitian oleh Adib Rifqi Setiawan yang berfokus pada perancangan lembar kerja literasi sains untuk pembelajaran daring dalam bahasan COVID-19 bagi sekolah dasar. Penelitian ini menunjukkan bahwa rancangan lembar kegiatan dapat ditanggapi oleh peserta didik namun pada pelaksanaan, mengungkap fakta bahwa literasi saintifik belum dilatih secara optimal (Setiawan, 2020). Kedua, penelitian Firman dan Sari Rahayu Rahman yang memiliki fokus kajian terhadap pembelajaran online bagi mahasiswa. Penelitian ini menunjukkan bahwa mahasiswa mempunyai fasilitas dalam pembelajaran online, pembelajaran online memotivasi mahasiswa untuk aktif belajar, dan perilaku social distancing dapat diterapkan secara lebih efektif (Firman \& Rahayu, 2020). Ketiga, penelitian Indra Murti Wulandari yang mengungkap peran guru sangat penting untuk mencegah COVID-19 melalui pengoptimalan Unit Kesehatan Sekolah (UKS) dengan mengkoordinasikan layanan kesehatan sekolah dengan layanan kesehatan setempat untuk mengadakan penyemprotan desinfektan di lingkungan sekolah dalam seminggu sekali (Wulandari, 2020). Keempat, penelitian yang dilakukan oleh Idad Suhada, Tuti Kurniati, Ading Pramadi, dan Milla Listiawati yang menunjukkan bahwa penggunaan aplikasi Google Classroom dalam pembelajaran daring pada masa pandemi COVID-19 sudah cukup baik dan efektif, hanya saja akan lebih baik apabila dipadukan dengan media lainnya (Suhada, Kurniati, Pramadi, \& Listiawati, 2020). Dari beberapa tema tersebut, tema mengenai kebijakan pendidikan dasar Islam masih kurang mendapatkan perhatian, oleh sebab itu perlunya suatu kajian untuk membahas secara rinci tentang model kebijakan pendidikan dasar Islam di era pandemi COVID-19.

Kebijakan yang ditetapkan dalam pendidikan dasar Islam sangat penting untuk diketahui, mengingat merebaknya virus Covid-19 serta upaya pencegahan yang dilakukan kepada usia pendidikan dasar (SD/MI dan SMP/MTs). Usia peserta didik dala tahapan tersebut masih tergolong rentan karena imunitas tubuh belum terlalu kuat serta belum memiliki dasar ataupun prinsip dalam mengarungi kehidupan. Anak-anak memerlukan imbingan dan panduan, baik secara tertulis ataupun melalui tauladan, agar mereka tidak salah dalam berbuat. Kebijakan senantiasa berubah menyesuaikan situasi dan kondisi, perkembangan perubahan kebijakan perlu diamati dan dipatuhi, karena kebijakan dibuat berdasarkan berbagai pendapat dan pertimbangan agar segala sesuatu dapat dipertahankan dan diperjuangkan walaupun situasi dan kondisi kurang memungkinkan. 


\section{METODE PENELITIAN}

Penelitian yang peneliti gunakan melalui pendekatan kualitatif yaitu penelitian untuk meneliti objek secara alami (Basuki, 2011). Peneliti berperan sebagai kunci dalam pengambilan sampel dan sumber data dengan menggunakan metode studi pustaka dari berbagai referensi jurnal internasional, jurnal nasional, dan buku ber-ISBN dalam 10 tahun terakhir. Penelitian dilaksanakan selama 3 bulan, sejak bulan Maret hingga bulan Mei tahun 2020. Peneliti menggunakan metode studi kasus agar penelitian lebih kuat dan berbobot serta dapat dipertanggungjawabkan kebenarannya. Subjek penelitian dalam penelitian ini meliputi Kemendikbud, Kemenag, Badan Standar Nasional Pendidikan (BSNP), dan Kepala MI Salafiyah Tajungsari Kecamatan Tlogowungu Kabupaten Pati Provinsi Jawa Tengah. Teknik pengumpulan data menggunakan observasi, wawancara, dan dokumentasi berupa surat edaran dari Kemenag, Kemendikbud, dan Pemerintah Daerah. Analisis data yang dilakukan diantaranya, pertama peneliti melakukan pengumpulan data dan fakta di lapangan, kedua peneliti memilah data yang relevan dengan penelitian, ketiga peneliti menyajikan data, keempat, peneliti menarik kesimpulan dan verifikasi data (Raco, 2018). Teknik uji keabsahan data peneliti peroleh melalui triangulasi metode dan triangulasi sumber.

\section{HASIL DAN PEMBAHASAN}

\section{Sekilas tentang COVID-19}

Sejak bulan Desember tahun 2019, di Wuhan, Cina, wabah penyakit Coronavirus 2019 (COVID-19) telah menyebar, penyakit ini diakibatkan oleh sindrom pernafasan akut yang parah yaitu coronavirus 2 (SARS-CoV-2). Karakteristik epidemiologis dan klinis pasien yang terpapar COVID-19 telah dilaporkan, namun faktor resiko untuk kematian dan perjalanan klinis penyakit yang terperinci, termasuk pelepasan virus, belum ada penjelasan yang mampu dijadikan pedoman. Sejumlah 191 pasien (135 dari Rumah Sakit Jinyintan dan 56 dari Rumah Sakit Paru Wuhan) dalam penelitian Fei Zhou, dkk. dilibatkan dalam penelitian ini. Hasilnya sebanyak 137 pasien dipulangkan dan 54 meninggal di rumah sakit. 91 pasien (48\%) memiliki komorbiditas, hipertensi menjadi yang paling umum 58 pasien (30\%), diikuti oleh diabetes 36 pasien (19\%) serta penyakit jantung koroner 15 pasien (8\%). Studi kohort retrospektif yang dilakukan oleh Zhou,dkk. mengidentifikasi beberapa faktor resiko kematian terhadap orang dewasa di Wuhan yang saat itu dirawat di rumah sakit dengan penyakit jenis COVID-19 lebih tinggi daripada orang yang lebih muda usianya, apalagi disertai dengan beragam penyakit lainnya (Zhou dkk., 2020).

Data awal dari Tiongkok menunjukkan bahwa mayoritas kematian akibat penyakit coronavirus pada 2019 (COVID-19) terjadi pada orang dewasa yang usianya lebih dari 60 tahun dan kebanyakan memiliki kondisi kesehatan yan kurang baik. Deskripsi awal penelitian pasien COVID-19 di Amerika Serikat menunjukkan bahwa kematian tertinggi pada orang berusia lebih dari 85 , mulai dari $10 \%$ hingga $27 \%$, diikuti oleh $3 \%$ hingga $11 \%$ di antara orang berusia $65-84$ tahun, $1 \%$ hingga 3\% di antara orang berusia 55-64 tahun, kurang dari 1\% di antara orang berusia 20-54 tahun, dan tidak ada kematian di antara orang berusia kurang dari 19 tahun. COVID-19 dapat menyebabkan penyakit parah, termasuk rawat inap, masuk ke unit perawatan intensif, dan 
Muh. Syauqi Malik \& Erni Munastiwi

kematian, terutama golongan orang dewasa yang lebih tua. Setiap orang dapat mengambil tindakan, seperti menjaga jarak sosial, untuk membantu memperlambat penyebaran COVID-19 dan melindungi orang dewasa yang lebih tua dari penyakit parah (COVID \& Team, 2020).

Pemerintah Indonesia melalui Keputusan Presiden RI no. 12 th. 2020 menetapkan COVID-19 dikategorikan dalam bencana nasional sejak tanggal 13 April tahun 2020 (Keputusan Presiden RI, 2020). Beberapa upaya pencegahan penyebaran COVID-19 adalah sebagai berikut:

1. Mencuci tangan memakai hand sanitizer atau memakai sabun minimal dalam durasi 20 detik atau lebih untuk membasmi kuman dan bakteri termasuk virus COVID-19.

2. Menghindari menyentuh area wajah. COVID-19 disinyalir mampu memasuki anggota tubuh melalui mata, mulut, dan hidung.

3. Menggunakan etika saat bersin atau batuk di tempat umum karena cairan yang keluar pada saat batuk atau bersin mampu menjadi media penularan virus COVID-19.

4. Menggunakan masker untuk meminimalisir penularan. Gunakan masker saat keluar rumah atau saat berkumpul dengan banyak orang, penggunaan masker dapat menangkal masuknya virus COVID-19 ke dalam tubuh bahkan di beberapa daerah penggunaan masker merupakan suatu kewajiban bagi Warga Negara Indonesia.

5. Menghindari interaksi secara langsung seperti bersalaman atau berpelukan untuk mengurangi penyebaran virus COVID-19.

6. Penerapan social distancing atau physical distancing dengan jarak aman sekitar 1 meter. Hal ini sangat digemakan oleh pemerintah maupun media massa karena dapat mengurangi resiko terpapar COVID-19.

7. Mencuci bahan-bahan makanan. Senantiasa mencuci bahan makanan juga sangat diperlukan agar makanan yang dimasak terjaga kebersihannya dan steril dari berbagai macam kuman penyakit.

8. Membersihkan barang-barang baik barang perabotan rumah ataupun pakaian yang dikenakan sehari-hari secara rutin.

9. Meningkatkan imun tubuh. Pada dasarnya virus COVID-19 menyerang imunitas tubuh, jadi perlu ditingkatkan imun tubuh dengan sering-sering berolahraga dan menjaga kondisi hati agar senantiasa bahagia.

Penanganan COVID-19 diupayakan dengan sangat gencar oleh pemerintahan dunia maupun Indonesia. Saat artikel ini ditulis (11 Mei 2020), data terakhir penyebaran COVID-19 di dunia dari 215 negara yang terkonfirmasi terinfeksi COVID-19 sebanyak 3.925.815 jiwa dengan angka kematian mencapai 274.488. Sedangkan di Indonesia kasus positif COVID-19 mencapai angka 14.032 jiwa dengan kesembuhan sebanyak 2.698 dan angka kematiannya mencapai 973 jiwa. Total kesembuhan warga Indonesia yang berada di luar negeri mencapai 50,6\%. 


\section{Data Sebaran}

Global

Negara

215

Terkonfirmasi

3.925 .815

Meninggal

274.488

These Teralkin: 10-05-2020| Sumber:

WHO

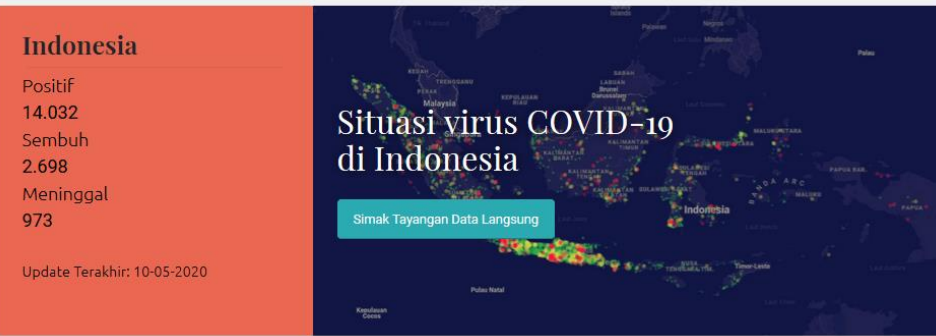

Gambar 1. Data Sebaran COVID-19 di Dunia dan di Indonesia (COVID-19, 2020)

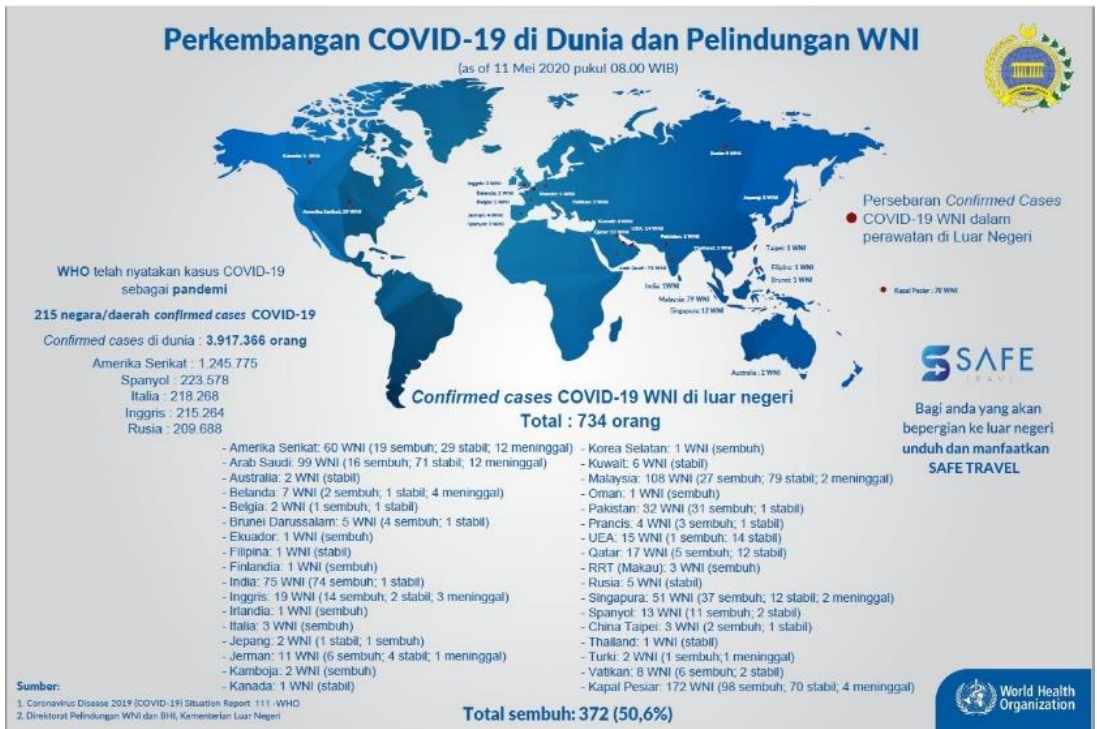

Gambar 2. Perkembangan COVID-19 WNI di luar negeri ("MoFA Indonesia di Twitter," 2020)

\section{Model Kebijakan Pendidikan Dasar Islam sebelum Pandemi COVID-19}

Kebijakan mempunyai domain yang sangat luas. Kebijakan berasal dari bahasa Inggris policy berarti mengurus kepentingan umum atau administrasi pemerintah (Hasbullah, 2015). Kebijakan disebut juga aturan tertulis berupa keputusan formal dalam organisasi dan sifatnya mengikat, mengatur individu untuk berperilaku dengan tujuan memperoleh nilai baru dalam masyarakat. Kebijakan seharusnya dapat digunakan sebagai pedoman dalam bertindak (Dunn, 2017). Kebijakan merupakan pedoman untuk melakukan aktivitas. Pedoman tersebut dapat bersifat umum, khusus, jelas, remang-remang, luas, sempit, mengekang, longgar ataupun yang lainnya yang disesuaikan dengan situasi dan kondisi kebijakan dibuat (Wahab, 2012). 
Pendidikan dasar yaitu jenjang pendidikan yang ditapaki oleh peserta didik di tingkat Sekolah Dasar atau Madrasah Ibtidaiyah dan Sekolah Menengah Pertama atau Madrasah Tsanawiyah. Peserta didik dalam fase tersebut memiliki karakteristik unik berdasarkan pandangan pedagogi ataupun psikologi (Dewi, Zukhri, Dunia, \& Erg, 2014). Pendidikan dasar yaitu bagian terpadu dari sistem pendidikan nasional yang diberi jangka waktu hingga 9 tahun, yaitu masa SD selama 6 tahun dan masa SMP selama 3 tahun (Taufiq, 2014). Sedangkan pendidikan dasar Islam sama dengan pendidikan dasar, hanya mendapatkan tambahan kata Islam berarti untuk tingkat SD setara dengan MI (Madrasah Ibtidaiyah) dan SMP setara dengan MTs (Madrasah Tsanawiyah).

Pandemi covid sangat tidak diprediksi sebelumnya atau datang secara tiba-tiba, hal itu dapat dilihat dari surat edaran Kemenag RI nomor B-87/Dj.I/Dt.I.I.1/PP.01.1/01/2020 mengenai ketentuan melaksanakan ujian pada madrasah berdasarkan pasal 5 Permendikbud no. 43 tahun 2019. Dalam keterangannya ujian dilaksanakan dalam bentuk penugasan, bentuk tes tulis, portofolio, dan bentuk lain berdasarkan Standar Nasional Pendidikan. Dalam hal ini juga telah dilakukan penyusunan kisi-kisi oleh guru mata pelajaran di masing-masing madrasah (Direktur KSKK Madrasah, 2020).

Prosedur Operasional Standar (POS) dalam menyelenggarakan Ujian Nasional (UN) pada tahun ajaran 2019/2020 telah diterbitkan oleh BSNP dengan nomor 0051/P/BSNP/XI/2019 sangat detail dan terperinci hingga 82 halaman. Pembahasan di dalamnya membahas tentang konsep UN, persyaratan peserta UN, ketentuan penyelenggara UN, media UN, perbaikan UN, pemeriksaan UN, KKM dalam UN, pemantauan dan evaluasi UN, rincian biaya operasional, prosedur penyelenggaraan, serta lainnya yang sangat terperinci dan belum ada yang menerangkan tentang akan terjadinya pandemi COVID-19 (BSNP, 2019). POS penyelenggaraan Ujian Nasional didukung oleh Permendikbud no. 43 tahun 2019 yang menerangkan tentang hal-hal teknis berhubungan dengan penyelenggaraan Ujian Nasional tahun 2019/2020 sebagai penegasan dan pemantapan berkaitan dengan POS BSNP tentang akan diselenggarakannya Ujian Nasional dengan persiapan yang matang, namun di kemudian hari Ujian Nasional ternyata dihapuskan untuk tahun pelajaran 2019/2020 (Menteri Pendidikan dan Kebudayaan Republik Indonesia, 2020b).

Berkaitan dengan Ujian Nasional, sebenarnya sudah ada kebijakan baru dari Nadiem Anwar Makarim, Menteri Pendidikan RI bahwa Ujian Nasional tahun 2020 merupakan ujian nasional yang terakhir kalinya, namun pada kenyataannya tahun 2020 sudah tidak dilaksanakan Ujian Nasional karena kendala COVID-19. Rencananya di tahun 2021, UN berubah menjadi Asesmen Kompetensi Minimum (AKM) dan Survei Karakter. AKM digunakan untuk mengukur kemampuan minimal yang dibutuhkan oleh peserta didik serta pemetaan madrasah ataupun sekolah dan daerah berdasarkan kompetensi minimal. Beberapa hal yang diangkat dalam kebijakan baru ini meliputi literasi (kemampuan menalar menggunakan bahasa), numerasi (kemampuan menalar menggunakan matematika), dan karakter yang mengacu pada Programme for International Student Assessment (PISA) dan Trends in International Mathematics and Science Study (TIMSS). Hal ini dilandaskan beberapa pertimbangan, pertama, materi UN sangat padat dan cenderung hanya menguji penguasaan konten, masih sedikit mengenai penalaran. Kedua, Ujian 
Nasional menjadi momok yang mengerikan bagi peserta didik, pendidik, dan wali murid karena UN digunakan sebagai tolok ukur keberhasilan pencapaian dalam pendidikan, padahal UN seharusnya digunakan sebagai pemetaan mutu sistem pendidikan nasional. Ketiga, UN hanya mengukur aspek kognitif, belum menyentuh karakter (Sugiharto, 2020).

Kebijakan yang mendapat sorotan publik dan sempat viral di media massa salah satunya adalah tentang merdeka belajar dengan indikator Rencana Pelaksanaan Pembelajaran (RPP) cukup hanya 1 halaman saja. Bagi penulis itu merupakan tindakan yang bagus, karena selama ini pendidik disibukkan dengan administrasi yang lumayan menguras tenaga dan pikiran seperti halnya RPP yang sampai ratusan halaman. Tugas utama pendidik adalah mendidik bukan berkutat dengan lembar kertas yang berisi tulisan hasil modifikasi dari berbagai sumber, walaupun itu demi kebaikan namun pekerjaan guru semakin berat dengan administrasi-administrasi yang tidak ada habisnya. Dengan menggunakan RPP 1 halaman ini diharapkan pendidik bebas memilih, membuat, dan mengembangkan RPP sesuai dengan minat peserta didik. Komponen penting dalam RPP ini meliputi 3 komponen inti, pertama, tujuan pembelajaran, kedua, kegiatan pembelajaran, dan ketiga asesmen. Penulisan RPP diharapkan dilakukan secara efektif dan efisien sehingga pendidik mempunyai waktu luang untuk merancang serta memberikan evaluasi terhadap pembelajaran yang telah dilakukan (Sugiharto, 2020).

Kebijakan pendidikan dasar sebelum pandemi COVID-19 berjalan sesuai dengan standar penyelenggaraan satuan pendidikan di setiap lingkungan masing-masing. Seperti halnya penggunaan kurikulum 2013 yang identik dengan pembelajaran tematik. Pembelajaran tematik menggunakan Buku Siswa dan Buku Guru kurikulum 2013 edisi revisi 2017. Dalam Kurikulum 2013 juga terdapat Kriteria Ketuntasan Minimal (KKM) pada setiap rumpun pelajaran, Pemetaan Kompetensi Dasar, penyusunan perangkat pembelajaran mulai dari Program Tahunan, Program Semester, Silabus Pembelajaran, dan Rencana Pelaksanaan Pembelajaran, serta penilaian yang terdiri dari penilaian sikap sosial dan spiritual, pengetahuan, dan keterampilan.
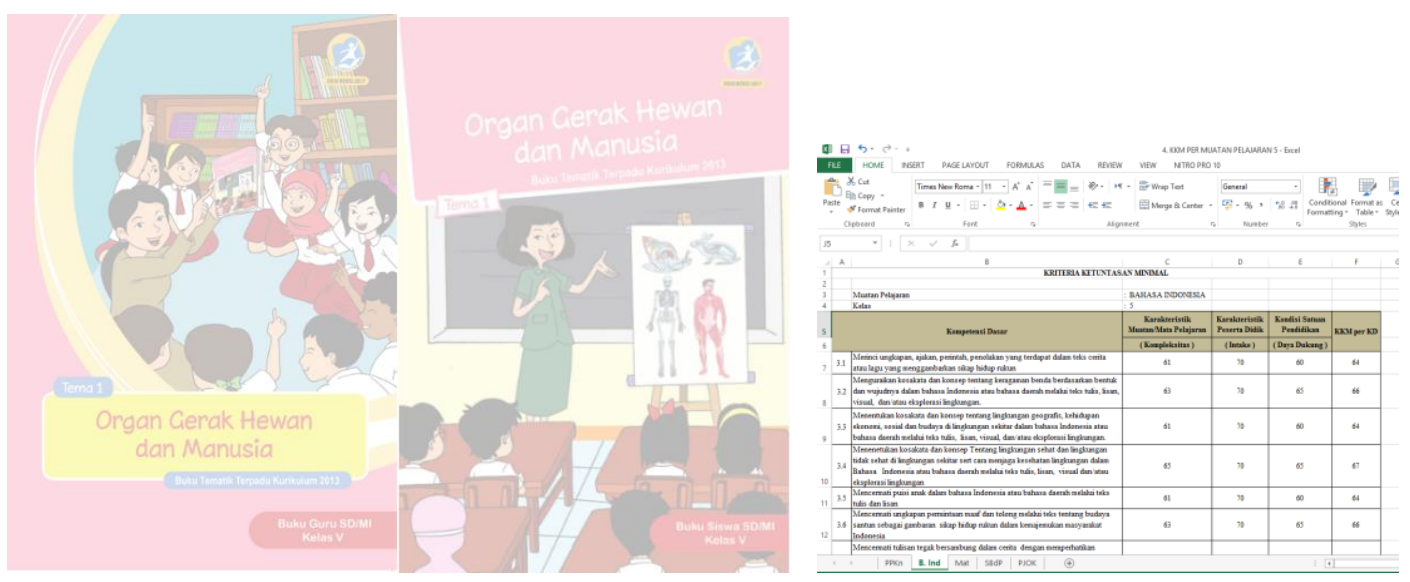

Gambar 3 - 5. Buku Siswa, Buku Guru, KKM 
Muh. Syauqi Malik \& Erni Munastiwi
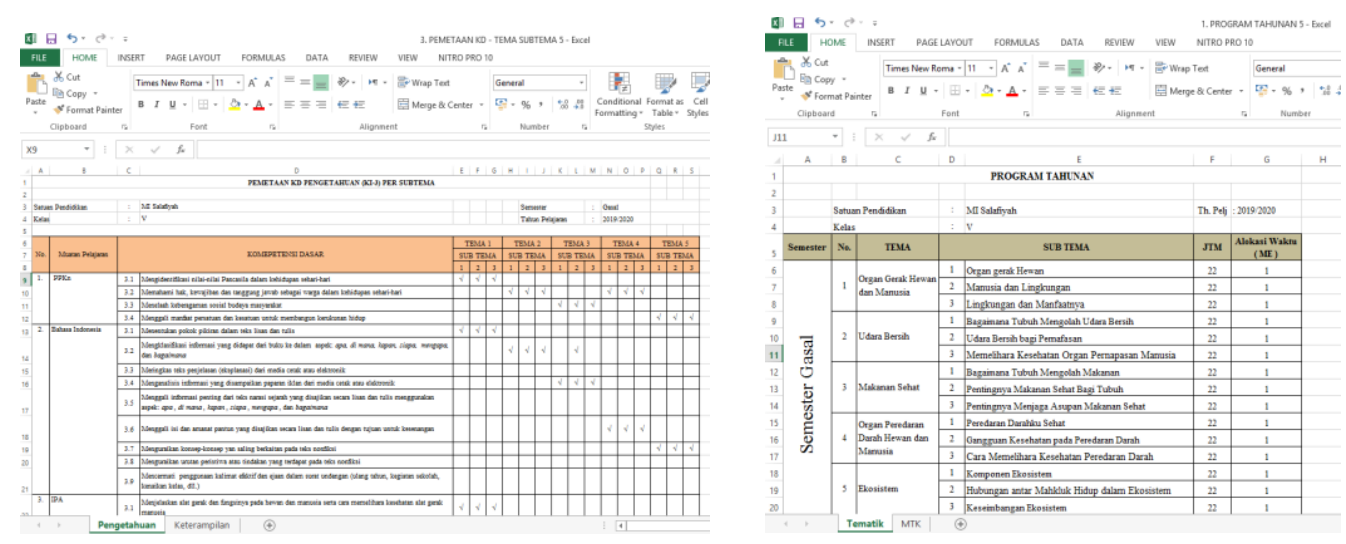

Gambar 6 dan 7. Pemetaan KD dan Program Tahunan
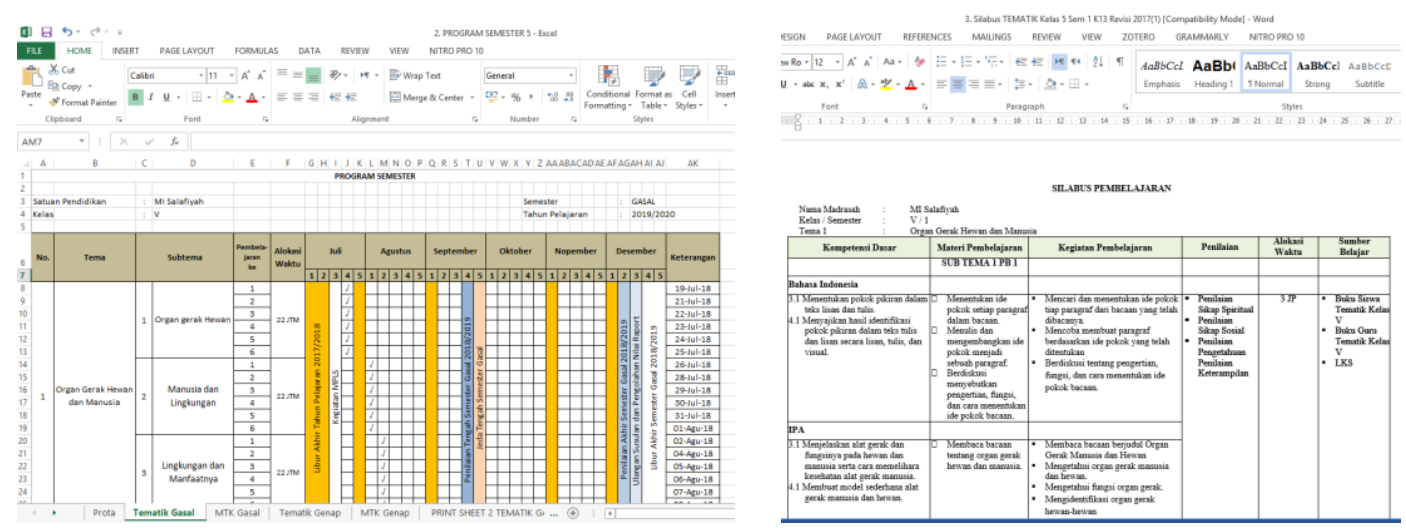

Gambar 8 dan 9. Program Semester dan Silabus Pembelajaran
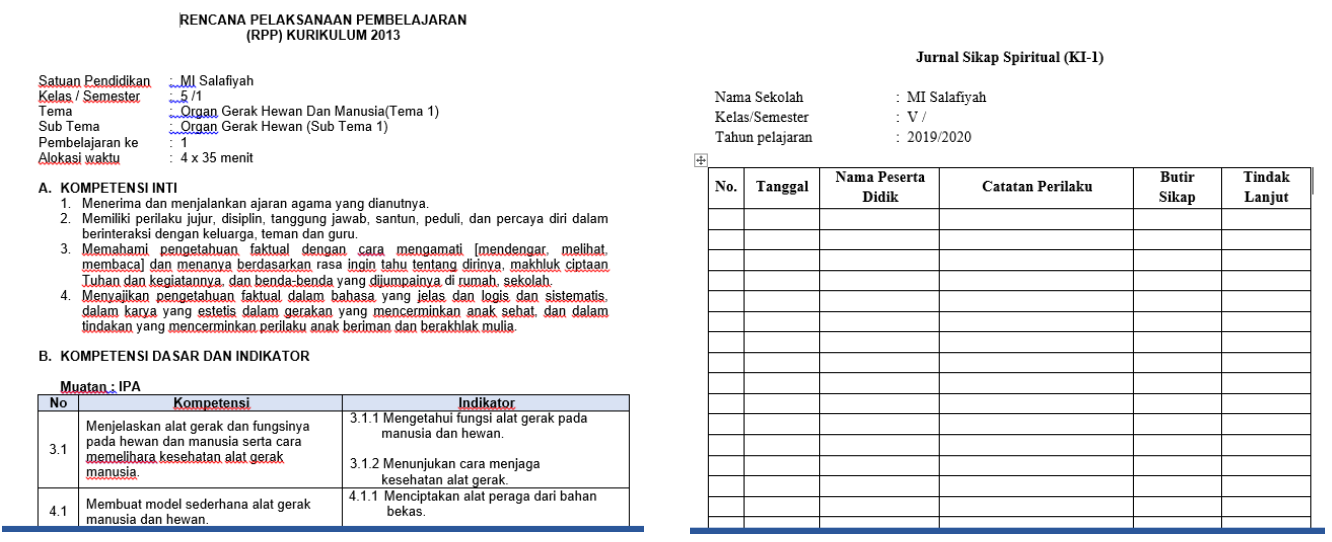

Gambar 10 dan 11. RPP dan Penilaian Sikap Spiritual 

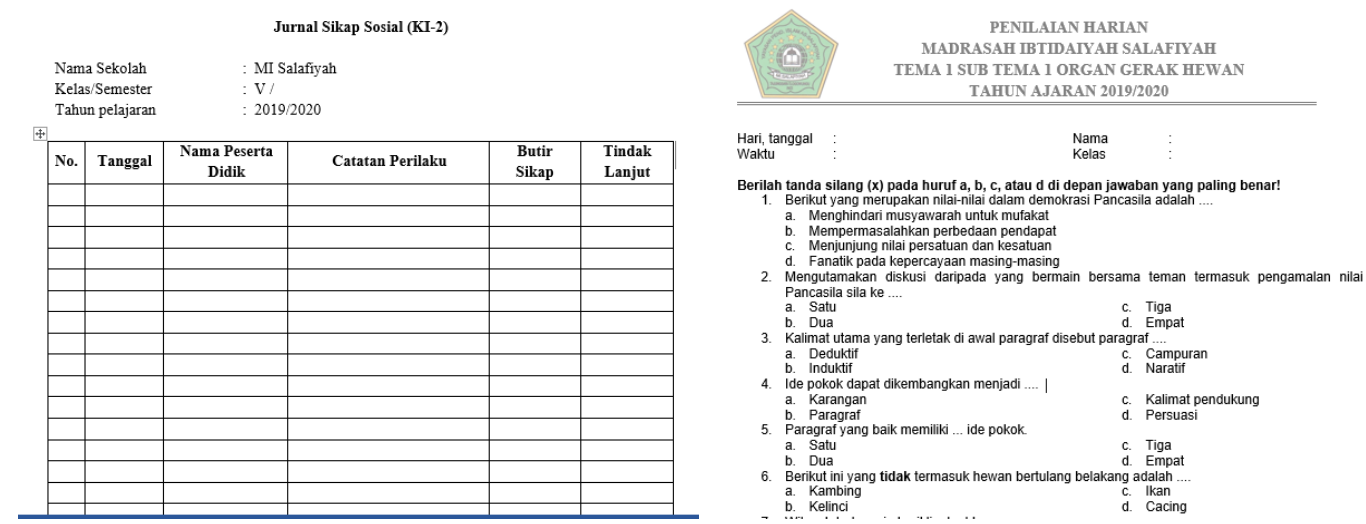

Gambar 12 dan 13. Penilaian Sikap Sosial dan Penilaian Pengetahuan

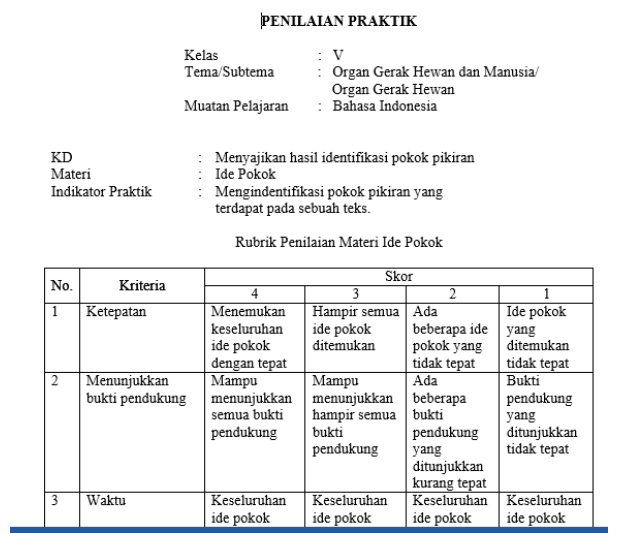

Gambar 14. Penilaian Keterampilan

\section{Model Kebijakan Pendidikan Dasar Islam saat Pandemi COVID-19}

Proses kebijakan pendidikan dasar Islam masa pandemi COVID-19 dimulai sejak 12 Maret 2020, BSNP mengeluarkan instruksi nomor 0113/SDAR/BSNP/III/2020 tentang penyelenggaraan Ujian nasional yang tetap dilakukan sesuai jadwal dengan memperhatikan protokol kesehatan untuk mencegah penyebaran COVID-19. Isi surat tersebut yaitu:

1. Menghindari kontak fisik sebelum ujian, selama ujian, dan setelah pelaksanaan ujian;

2. Mencuci tangan sebelum ujian dan setelah ujian;

3. Apabila mempunyai keluhan dengan gejala batuk, demam, sakit tenggorokan, pilek, atau sesak napas, harap tidak memaksakan hadir untuk mengikuti ujian.

4. Membersihkan ruang ujian sebelum dan sesudah digunakan

5. Tidak saling meminjamkan alat tulis 
Muh. Syauqi Malik \& Erni Munastiwi

6. Apabila dalam pelaksanaan terdapat peserta yang memiliki gejala COVID-19, kepala madrasah segera meminta peserta memeriksakan diri ke fasilitas kesehatan terdekat (BSNP, 2020a).

Kemenag RI juga ikut serta mengambil kebijakan dengan diterbitkannya surat edaran no. 069-08/2020 mengenai pedoman pelaksanaan penanganan COVID-19 di area publik dalam lingkungan Kemenag dengan poin-poin sebagai berikut:

1. Memastikan seluruh area umum terjaga kebersihannya dengan menggunakan desinfektan;

2. Melakukan cek suhu tubuh pada setiap orang sebelum masuk tempat umum, apabila lebih dari 38 derajat dianjurkan agar secepatnya memeriksakan diri ke fasilitas kesehatan terdekat;

3. Memastikan terdapat ruang isolasi pada acara-acara besar;

4. Menggemakan ajakan cuci tangan secara teratur dan menyeluruh melalui berbagai macam media;

5. Mengadakan sosialisasi terkait etika bersin atau batuk di tempat umum;

6. Mengadakan pembaruan secara reguler terkait COVID-19 (Menteri Agama RI, 2020b).

Pada tanggal yang sama, Kemendikbud RI menerbitkan edaran no. 3 tahun 2020 tentang mencegah virus COVID-19 dalam satuan pendidikan, beberapa upaya yang dilakukan diantaranya:

1. Menggunakan peran Usaha Kesehatan Sekolah (UKS) secara optimal;

2. Berkoordinasi dengan Dinas Kesehatan tentang kesiapannya dalam menghadapi kemungkinan COVID-19;

3. Mempersiapkan alat untuk cuci tangan di lingkungan strategis dalam kelas;

4. Mensosialisasikan budaya cuci tangan minimal 20 detik serta membiasakan pola hidup sehat;

5. Memberikan izin apabila pendidik atau peserta didik sakit dengan gejala yang telah disebutkan sebelumnya;

6. Tidak memberikan sanksi bagi yang tidak masuk dikarenakan sakit;

7. Tidak mengadakan acara dengan mengumpulkan banyak orang;

8. Membatasi tamu yang berasal dari luar satuan pendidikan (Menteri Agama RI, 2020b).

Tepat pada tanggal 24 Maret 2020 BSNP mengeluarkan siaran pers mengenai usulan pembatalan UN tahun ajaran 2019/2020 dengan nomor surat 0003/PR/BSNP/III/2020 setelah melalui berbagai pertimbangan demi kemaslahatan bersama (BSNP, 2020b). Usulan tersebut ditindaklanjuti oleh Kemendikbud melalui edaran no. 4 tahun 2020 dengan beberapa keputusan, yaitu:

1. Penyelenggaraan UN tahun 2020 dibatalkan dan UN tidak lagi menjadi syarat lulus ataupun syarat menapaki jenjang pendidikan selanjutnya. 
2. Ujian sekolah tidak diharuskan mengevaluasi ketuntasan pencapaian kurikulum secara holistik dan tidak boleh dilakukan dalam bentuk mengumpulkan siswa. Apabila tidak melakukan ujian sekolah, pengambilan nilai dapat memakai nilai dari lima semester terakhir.

3. Proses belajar dari rumah menggunakan sistem daring tidak dibebani tuntutan untuk menuntaskan seluruh pencapaian kurikulum, serta disesuaikan dengan kondisi siswa.

4. Penerimaan siswa baru boleh tetap dilakukan dengan tetap mengikuti protokol kesehatan, untuk jalur prestasi menggunakan akumulasi nilai rapor selama lima semester terakhir (Menteri Pendidikan dan Kebudayaan Republik Indonesia, 2020a).

Berdasarkan hal-hal tersebut, Dinas Pendidikan dan Kebudayaan Prov. Jateng mengeluarkan surat edaran no. 443.2/09002 tentang yang berisi penegasan atas keputusan Kemendikbud di atas dengan tambahan masa belajar di rumah yang asalnya diberlakukan mulai tanggal 16 hingga 29 Maret 2020 diperpanjang sampai dengan 13 April 2020. Pembelajaran tidak boleh dilakukan secara berkelompok dan tidak diperkenankan melakukan penarikan sumbangan dalam bentuk apapun dalam satuan pendidikan negeri (Dinas Pendidikan dan Kebudayaan Provinsi Jawa Tengah, 2020). Hal ini mendapatkan penguatan oleh Kemenag Prov. Jateng melalui surat dengan nomor 4281/Kw.11.2/1/PP.00/03/2020 yang ditujukan kepada kepala kantor kementerian agama kabupaten atau kota dan seluruh kepala madrasah se-Jawa Tengah (Menteri Agama RI, 2020a).

Keputusan surat di atas sudah direvisi kembali sebelum akhir berlaku surat tersebut, Kemenag Provinsi Jawa Tengah mengeluarkan kebijakan baru mengenai perpanjangan kegiatan belajar dari rumah hingga 30 April 2020 dengan nomor surat 5605/Kw.11.2/1/PP.00/04/2020. Belajar dari rumah diharapkan menitikberatkan terhadap kecakapan hidup, penguatan nilai karakter, dan keterampilan beribadah di tengah keluarga (Menteri Agama Provinsi Jawa Tengah, 2020b). Hal ini mendapatkan respons dari berbagai media massa, seperti halnya belajar dari rumah melalui TVRI yang menyajikan materi pembelajaran secara interaktif untuk jenjang PAUD hingga SMA dan sederajat serta ditambah program parenting untuk mendukung perkembangan anak.

Pada tanggal 27 April 2020 Menteri Agama RI kembali menerbitkan surat yang ditujukan kepada kepala kantor Kementerian Agama kabupaten atau kota dan seluruh kepala madrasah seJawa Tengah dengan nomor 2974/Kw.11.2/1/PP.00/04/2020 tentang perpanjangan kegiatan belajar mengajar jarak jauh yang semula diberlakukan sampai tanggal 30 April 2020 diperpanjang hingga 16 Mei 2020 (Menteri Agama RI, 2020c). Belum berakhir masa pemberlakuan keputusan tersebut, pada tanggal 15 Mei 2020 Menteri Agama mengeluarkan surat dengan nomor surat 5882/Kw.11.2/1/PP.000/05/2020 tentang perpanjangan belajar dari rumah hingga 30 Mei 2020 (Menteri Agama Provinsi Jawa Tengah, 2020a). 
Tabel 1. Tabulasi Model Kebijakan Pendidikan Dasar Islam di Era Pandemi COVID-19

\begin{tabular}{|c|c|c|c|c|}
\hline No & Tanggal & Nomor Surat & Sumber & Isi Surat \\
\hline 1 & $\begin{array}{l}12 \text { Maret } \\
2020\end{array}$ & 0113/SDAR/BSNP/III/2020 & BSNP & $\begin{array}{l}\text { Penyelenggaraan } \\
\text { Ujian nasional yang } \\
\text { tetap dilakukan } \\
\text { sesuai jadwal } \\
\text { dengan tetap } \\
\text { memperhatikan } \\
\text { protokol kesehatan }\end{array}$ \\
\hline 2 & $\begin{array}{l}12 \text { Maret } \\
2020\end{array}$ & 069-08/2020 & Kemenag RI & $\begin{array}{l}\text { Pelaksanaan } \\
\text { Protokol } \\
\text { Penanganan } \\
\text { COVID-19 di Area } \\
\text { Publik dalam } \\
\text { Lingkungan } \\
\text { Kementerian } \\
\text { Agama }\end{array}$ \\
\hline 3 & $\begin{array}{l}12 \text { Maret } \\
2020\end{array}$ & Edaran nomor 3 tahun 2020 & $\begin{array}{l}\text { Kemendikbud } \\
\text { RI }\end{array}$ & $\begin{array}{l}\text { Pencegahan } \\
\text { Corona Virus } \\
\text { Disease (COVID- } \\
\text { 19) Pada Satuan } \\
\text { Pendidikan }\end{array}$ \\
\hline 4 & $\begin{array}{l}24 \text { Maret } \\
2020\end{array}$ & 0003/PR/BSNP/III/2020 & BSNP & $\begin{array}{l}\text { Usulan pembatalan } \\
\text { UN tahun } \\
\text { pelajaran } \\
2019 / 2020\end{array}$ \\
\hline 5 & $\begin{array}{l}24 \text { Maret } \\
2020\end{array}$ & Edaran nomor 4 tahun 2020 & $\begin{array}{l}\text { Kemendikbud } \\
\text { RI }\end{array}$ & $\begin{array}{l}\text { Pelaksanaan } \\
\text { Kebijakan } \\
\text { Pendidikan dalam } \\
\text { Masa Darurat } \\
\text { Penyebaran } \\
\text { COVID- } 19\end{array}$ \\
\hline 6 & $\begin{array}{l}24 \text { Maret } \\
2020\end{array}$ & $443.2 / 09002$ & $\begin{array}{l}\text { Kemendikbud } \\
\text { Prov. Jateng }\end{array}$ & $\begin{array}{l}\text { Tambahan masa } \\
\text { belajar di rumah } \\
\text { yang asalnya } \\
\text { diberlakukan mulai } \\
\text { tanggal } 16 \text { hingga } \\
29 \text { Maret } 2020 \\
\text { diperpanjang } \\
\text { sampai dengan } 13 \\
\text { April } 2020\end{array}$ \\
\hline
\end{tabular}

$\begin{array}{lllll}7 & \text { 24 Maret } & 4281 / \mathrm{Kw} .11 .2 / 1 / \mathrm{PP} .00 / 03 / 2020 & \text { Kemenag } & \text { Tambahan masa } \\ 2020 & & \text { Prov. Jateng } & \text { belajar di rumah }\end{array}$




\begin{tabular}{|c|c|c|c|c|}
\hline & & & & $\begin{array}{l}\text { yang asalnya } \\
\text { diberlakukan } \\
\text { sampai dengan } 13 \\
\text { April } 2020\end{array}$ \\
\hline 8 & $\begin{array}{l}8 \text { April } \\
2020\end{array}$ & 5605/Kw.11.2/1/PP.00/04/2020 & Kemenag RI & $\begin{array}{l}\text { Perpanjangan } \\
\text { kegiatan belajar } \\
\text { dari rumah hingga } \\
30 \text { April } 2020\end{array}$ \\
\hline 9 & $\begin{array}{l}27 \text { April } \\
2020\end{array}$ & 2974/Kw.11.2/1/PP.00/04/2020 & Kemenag RI & $\begin{array}{l}\text { Perpanjangan } \\
\text { kegiatan belajar } \\
\text { mengajar jarak jauh } \\
\text { yang semula } \\
\text { diberlakukan } \\
\text { sampai tanggal } 30 \\
\text { April } 2020 \\
\text { diperpanjang } \\
\text { hingga } 16 \text { Mei } 2020\end{array}$ \\
\hline 10 & $\begin{array}{l}13 \text { Mei } \\
2020\end{array}$ & 5882/Kw.11.2/1/PP.000/05/2020 & Kemenag RI & $\begin{array}{l}\text { Perpanjangan } \\
\text { belajar dari rumah } \\
\text { hingga } 30 \text { Mei } 2020\end{array}$ \\
\hline
\end{tabular}

Berdasarkan data-data dan analisis yang telah disebutkan, dapat disimpulkan bahwa model kebijakan pendidikan dasar Islam di era pandemi COVID-19 senantiasa mengalami perubahan seiring dengan perkembangan mengenai penyebaran virus COVID-19. Kebijakan diberlakukan agar pendidikan tetap mampu berjalan menghadapi segala rintangan, walau dengan berbagai penyesuaian. Memang bukanlah hal mudah menghadapi pandemi COVID-19 karena banyak pantangan-pantangan yang harus dilakukan dalam memutus mata rantai penyebaran virus COVID-19. Inovasi dalam pembelajaran harus senantiasa dikembangkan melalui media teknologi informasi dan komunikasi agar proses pembelajaran tetap berlangsung secara efektif dan efisien.

Peneliti juga melakukan wawancara untuk lebih menguatkan hasil penelitian, yaitu wawancara terhadap Kepala MI Salafiyah Tajungsari Kecamatan Tlogowungu Kabupaten Pati yang madrasahnya juga terkena dampak akibat pandemi COVID-19. Kebijakan yang diberlakukan dalam proses belajar mengajar disesuaikan dengan arahan dari pemerintah yang telah penulis paparkan sebelumnya. MI Salafiyah Tajungsari juga memiliki kebijakan teknis yang dilaksanakan dengan kerja sama wali murid, seperti pemantauan anak dalam beribadah wajib utamanya salat 5 waktu. Sistem pembelajarannya menggunakan aplikasi Whats $A p p$ Group di setiap kelas, untuk kelas dengan bantuan wali murid dalam mendampingi putra-putrinya. Selalu mengingatkan anak agar menjaga kesehatan, olahraga teratur 10 - 15 menit setiap hari, dan mengikuti pola hidup sehat agar imun tubuh tetap terjaga.

Kegiatan Ramadhan juga dilakukan secara daring, sebelum pembelajaran dimulai anakanak diminta untuk tadarus Alquran atau Jilid sesuai dengan tingkatannya masing-masing sejak 
Muh. Syauqi Malik \& Erni Munastiwi

pukul 06.00 - 07.00 WIB dari rumah masing-masing. Setelah itu proses pembelajaran dilaksanakan mulai pukul 07.00 sampai 10.30 WIB. Kontrol kegiatan dilakukan secara online melalui Google Forms yang diisi oleh siswa setiap harinya, namun apabila mempunyai kendala bisa dilakukan dengan mencatat keseharian di buku catatan untuk dievaluasi oleh guru kelasnya masing-masing saat kembali ke sekolah nanti. Untuk meningkatkan kompetensi lulusan, MI Salafiyah Tajungsari tetap mempertahankan tradisi kelulusan yang telah dilakukan secara turuntemurun, yaitu hafal tahlil, Surah Yasin, dan Juz 'Amma. Tradisi baik ini harus senantiasa dilestarikan karena pembiasaan seperti ini bertujuan agar menanamkan rasa keimanan dan ketakwaan seorang hamba kepada penciptanya sehingga terbentuklah karakter religius yang hanya menyembah dan memohon pertolongan kepada Allah Swt (Hasanah \& Munastiwi, 2019). Kebiasaan baik yang dilakukan secara terus-menerus dapat mengundang tindakan baik selanjutnya, hal ini sesuai dengan penelitian Ria Astuti dan Erni Munastiwi yang membiasakan perilaku baik dalam penerapan pembelajaran tauhid mampu memberikan dampak positif bagi anak, seperti memiliki pribadi yang religius, mengajak saudaranya untuk menunaikan sholat, dan memiliki budi pekerti yang baik (Astuti \& Munastiwi, 2018).

\section{SIMPULAN}

Pandemi COVID-19 telah melumpuhkan berbagai sektor yang tengah berjalan, bukan hanya di negara Indonesia namun juga di mancanegara. Sektor yang paling disorot dalam penelitian ini adalah sektor pendidikan, sektor pendidikan sangat membutuhkan perhatian karena pendidikan menentukan kemajuan peradaban. Model kebijakan dalam pendidikan di masa sebelum pandemi COVID-19 menggunakan Kurikulum 2013 dengan pendekatan scientific sebagai cirinya. Dalam kurikulum 2013 juga dibahas tentang Kriteria Ketuntasan Minimal (KKM) pada setiap rumpun pelajaran, Pemetaan Kompetensi Dasar, penyusunan perangkat pembelajaran mulai dari Program Tahunan, Program Semester, Silabus Pembelajaran, dan Rencana Pelaksanaan Pembelajaran, serta penilaian yang terdiri dari penilaian sikap sosial dan spiritual, pengetahuan, dan keterampilan. Pandemi COVID-19 membuat kebijakan tersebut berubah, muncul berbagai kebijakan baru yang disesuaikan dengan perkembangan pandemi COVID-19. Kebijakan baru harus dilakukan, karena hal yang sangat diperlukan adalah memutuskan rantai penyebaran COVID-19 dan tetap belajar walau di rumah saja.

\section{DAFTAR PUSTAKA}

Astuti, R., \& Munastiwi, E. (2018). Pendidikan Anak Usia Dini Berbasis Tauhid (Studi Kasus PAUD Ababil Kota Pangkalpinang). Al-Mudarris (Jurnal Ilmiah Pendidikean Islam), 1(2), $1-19$.

Basuki. (2011). Cara Mudah Menyusun Proposal Penelitian dengan Menggunakan Pendekatan Kualitatif (Kl). Yogyakarta: Pustaka Felicha.

BSNP. (2019). Prosedur Operasional Standar (POS) Penyelenggaraan Ujian Nasional Tabun Pelajaran 2019/2020. Jakarta: Badan Standar Nasional Pendidikan. 
BSNP. (2020a). Protokol Pelaksanaan UN Tabun 2019/2020 untuk Penanganan Penyebaran COVID19. Badan Standar Nasional Pendidikan.

BSNP. (2020b). Siaran Pers Badan Standar Nasional Pendidikan Tentang Usulan Pembatalan Ujian Nasional Tabun Pelajaran 2019/2020. Badan Standar Nasional Pendidikan.

COVID, C., \& Team, R. (2020). Severe outcomes among patients with coronavirus disease 2019 (COVID-19)_United States, February 12-March 16, 2020. MMWR Morb Mortal Wkly Rep, 69(12), 343-346.

COVID-19, G. T. P. P. (2020). Beranda | Gugus Tugas Percepatan Penanganan COVID-19. Diambil 11 Mei 2020, dari https://covid19.go.id/

Dewi, N. A. K., Zukhri, A., Dunia, I. K., \& Erg, M. (2014). Analisis Faktor-Faktor Penyebab Anak Putus Sekolah Usia Pendidikan Dasar di Kecamatan Gerokgak Tahun 2012/2013. Jurnal Pendidikan Ekonomi Undiksha, 4(1).

Dinas Pendidikan dan Kebudayaan Provinsi Jawa Tengah. (2020). Layanan Penyelenggaraan Pendidikan dalam Rangka Pencegahan Penularan dan Penyebaran Infeksi Corona Virus Disease (Covid-19) di Jawa Tengah. Pemerintah Provinsi Jawa Tengah.

Direktur KSKK Madrasah. (2020). Ketentuan Pelaksanaan Ujian-Ujian pada Madrasah. Kementerian Agama Republik Indonesia.

Dunn, W. N. (2017). Pengantar analisis kebijakan publik. Yogyakarta: Gajah Mada University Press.

Firman, F., \& Rahayu, S. (2020). Pembelajaran Online di Tengah Pandemi Covid-19. Indonesian Journal of Educational Science (IJES), 2(2), 81-89.

Hasanah, F. F., \& Munastiwi, E. (2019). Pengelolaan Pendidikan Karakter Religius Melalui Metode Pembiasaan di Taman Kanak-Kanak. Golden Age: Jurnal Ilmiah Tumbub Kembang Anak Usia Dini, 4(1), 35-46.

Hasbullah. (2015). Kebijakan Pendidikan dalam Perspektif Teori, Aplikasi, dan Kondisi Objektif Pendidikan di Indonesia. Jakarta: Rajawali Pers.

Keputusan Presiden RI. (2020). KEPPRES No. 12 Tabun 2020 tentang Penetapan Bencana Nonalam Penyebaran Corona Virus Disease 2019 (COVID-19) Sebagai Bencana Nasional JDIH BPK $\mathrm{RI}]$.

Mehta, P., McAuley, D. F., Brown, M., Sanchez, E., Tattersall, R. S., \& Manson, J. J. (2020). Covid-19: Consider Cytokine Storm Syndromes and Immunosuppression. The Lancet, 395(10229), 1033-1034.

Menteri Agama Provinsi Jawa Tengah. (2020a). KBM Daring dan Libur pada Madrasah di Jawa Tengah. Kementerian Agama Republik Indonesia.

Menteri Agama Provinsi Jawa Tengah. (2020b). Mekanisme Pembelajaran dan Penilaian Madrasah dalam Masa Darurat Pencegahan Penyebaran Covid-19. Kementerian Agama Republik Indonesia. 
Muh. Syauqi Malik \& Erni Munastiwi

Menteri Agama RI. (2020a). Mekanisme Pembelajaran dan Penilaian Madrasah dalam Masa Darurat Pencegahan Penyebaran Covid-19. Kementerian Agama Republik Indonesia.

Menteri Agama RI. (2020b). Pelaksanaan Protokol Penanganan Covid-19 pada Area Publik di Lingkungan Kementerian Agama. Kementerian Agama Republik Indonesia.

Menteri Agama RI. (2020c). Perpanjangan KBM Daring dan Jadwal Kelulusan Peserta Didik. Kementerian Agama Republik Indonesia.

Menteri Pendidikan dan Kebudayaan Republik Indonesia. (2020a). Pelaksanaan Kebijakan Pendidikan dalam Masa Darurat Covid-19. Kementerian Pendidikan dan Kebudayaan.

Menteri Pendidikan dan Kebudayaan Republik Indonesia. (2020b). Peraturan Menteri Pendidikan dan Kebudayaan Republik Indonesia Nomor 43 Tabun 2019. Kementerian Pendidikan dan Kebudayaan.

MoFA Indonesia di Twitter: “\#SahabatKemlu, berikut Perkembangan COVID-19 di Dunia \&amp; Pelindungan WNI per 11/05 pkl 08.00 WIB. Seorang WNI terkonfirmasi \#COVID19 di GB \&amp; 9 WNI sembuh di SG. Total WNI terkonfirmasi COVID-19 di luar negeri adalah 734: 372 sembuh, 41 meninggal \&amp; 321 dlm perawatan. \#IniDiplomasi https://t.co/VwThDE6vso" / Twitter. (2020). Diambil 11 Mei 2020, dari Twitter website: https://twitter.com/Kemlu_RI/status/1259654216722690051

Organization, W. H. (2020). Coronavirus Disease 2019 (Covid-19): Situation Report, 72.

Raco, J. (2018). Metode Penelitian Kualitatif. Jenis, Karakteristik, dan Keunggulannya. Jakarta: PT Grasindo.

Setiawan, A. R. (2020). Lembar Kegiatan Literasi Saintifik untuk Pembelajaran Jarak Jaub Topik Penyakit Coronavirus 2019 (COVID-19).

Sugiharto, B. (2020). Asessmen Kompetensi Minimal dan RPP Sederhana. Surakarta: UNS Press.

Suhada, I., Kurniati, T., Pramadi, A., \& Listiawati, M. (2020). Pembelajaran daring berbasis Google Classroom mahasiswa pendidikan biologi pada masa wabah Covid-19. Digital Library UIN Sunan Gunung Djati, 1-10.

Taufiq, A. (2014). Pendidikan Anak di SD. Yogyakarta: Universitas Terbuka.

Wahab, S. A. (2012). Analisis Kebijakan: Dari Formulasi ke Penyusunan Model-Model Implementasi Kebijakan Publik (Vol. 77). Jakarta: Bumi Aksara.

Wulandari, I. M. (2020). Peran Guru Mengoptimalkan Unit Kesehatan Sekolah Untuk Melakukan Pencegahan Covid-19. Edukatif: Jurnal Ilmu Pendidikan, 2(1), 71-76.

Zhou, F., Yu, T., Du, R., Fan, G., Liu, Y., Liu, Z., ... Gu, X. (2020). Clinical course and risk factors for mortality of adult inpatients with COVID-19 in Wuhan, China: A retrospective cohort study. The lancet. 